\title{
PERBEDAAN RERATA KEASAMAN MULUT BERBAGAI KELOMPOK KARIES GIGI PADA PASIEN DI RSGM BAITURRAHMAH PADANG
}

\author{
Defi Firdaus", Utmi Arma ${ }^{* *}$, Dhona Afriza** \\ "Mahasiswa FKG, Universitas Baiturrahmah, Padang \\ ${ }^{* *}$ Bagian Penyakit Mulut, FKG, Universitas Baiturrahmah, Padang
}

$\overline{\text { KATA KUNCI }}$

karies gigi,

demineralisasi,

mikroorganisme,

metabolisme, $\mathrm{pH}$.

\begin{abstract}
ABSTRAK
Riset kesehatan dasar tahun 2007 menyebutkan 72,1\% penduduk Indonesia terkena karies gigi. Karies gigi adalah suatu proses patologis jaringan keras gigi (email dan dentin) yang terjadi karena adanya interaksi berbagai faktor (multi-faktor) dalam rongga mulut. Karies gigi dimulai dengan terjadinya demineralisasi jaringan keras gigi yang kemudian diikuti dengan terjadinya kerusakan bahan organik gigi. Jaringan keras gigi yang termineralisasi akibat adanya asam hasil fermentasi karbohidrat oleh mikroorganisme, akan menjadi larut dan rusak. Keasaman mulut merupakan hasil metabolisme mikroorganisme pada sukrosa dapat mengakibatkan proses demineralisasi permukaan gigi. Derajat keasaman $(\mathrm{pH})$ lebih rendah dan mencapai derajat keasaman 5,5. Tujuan penelitian ini adalah untuk mengetahui tentang hubungan keasaman mulut terhadap karies gigi pada usia 16-25 tahun di RSGM Baiturrahmah. Penelitian ini bersifat survei analitik. Pengambilan sampel secara simple random sampling dengan jumlah sampel 35 orang. Dari hasil penelitian diperoleh $\mathrm{pH}$ rata-rata kelompok karies gigi yaitu $\mathrm{pH}$ rata-rata kelompok karies gigi ringan 7,13 $\pm 0,97$, $\mathrm{pH}$ rata-rata kelompok karies gigi sedang 5,75 $\pm 0,46$ dan $\mathrm{pH}$ rata-rata kelompok karies gigi berat $4,25 \pm 0,50$. Setelah diuji dengan ANOVA terdapat perbedaan yang signifikan diantara ketiga kelompok $(\rho=$ 0,000 ). Setelah dianalisa dengan uji statistik perbandingan $\mathrm{pH}$ saliva pada ketiga kelompok karies gigi terdapat hubungan yang signifikan ( $\rho$ $<0,05)$. Kelompok karies gigi ringan dengan karies gigi sedang $(\rho=$ $0,001)$, kelompok karies gigi ringan dengan karies gigi berat $(\rho=$ $0,000)$ dan kelompok karies gigi sedang dengan karies gigi berat $(\rho=$ $0,020)$. Dapat disimpulkan bahwa terdapat hubungan yang signifikan antara $\mathrm{pH}$ saliva dengan karies gigi.
\end{abstract}

\section{PENDAHULUAN}

Riset kesehatan dasar tahun 2007 menyebutkan $72,1 \%$ penduduk Indonesia terkena karies gigi. Bahkan dalam 12 bulan terakhir 23,4\% penduduk Indonesia mengeluhkan masalah gigi dan mulut (Suara Merdeka,2010). Begitu juga dengan usaha untuk mengatasinya belum terlihat hasil yang nyata bila diukur dengan indikator kesehatan gigi masyarakat, ini terlihat dari prevalensi karies gigi tidak berbeda banyak pada tahun 1973 dan 1983 yaitu sekitar 70\% (Riskesdas, 2007)

Karies dipersentasekan sekitar 30\% pada kelompok berusia 12 tahun, sekitar $60 \%$ pada kelompok 16 - 25 tahun, dan sekitar $80 \%$ pada 35 tahun ke atas. Jumlah rata-rata kerusakan gigi meningkat secara signifikan seiring umur namun tidak berasosiasi signifikan dengan daerah tempat tinggal. ${ }^{1}$ 
Periode pubertas (remaja) umur antara 14 sampai dengan 20 tahun. Pada masa pubertas ini terjadi perubahan hormonal yang dapat menimbulkan pembengkakan gusi, sehingga kebersihan mulut menjadi kurang terjaga. Hal inilah yang menyebabkan persentase karies lebih tinggi. ${ }^{2}$

Karies tahap di permulaan adalah pelarutan lapisan dalam email yang disebut karies dini atau dikenal dengan white spot. Proses pelarutan email disebut dekalsifikasi di bawah permukaan email akan terlihat secara klinis permukaan email yang kelihatan masih utuh, agak kasar, buram, warna opak atau putih. Secara klinis yang disebut dengan karies gigi ialah lubang (kavitas) yang sudah dapat dirasakan secara mekanis dengan sonde. Jadi karies gigi adalah suatu proses patologis jaringan keras gigi (email dan dentin) yang terjadi karena adanya interaksi berbagai faktor (multi-faktor) dalam rongga mulut. ${ }^{3,4}$

Karies pada gigi dimulai dengan terjadinya demineralisasi jaringan keras gigi yang kemudian diikuti dengan terjadinya kerusakan bahan organik gigi. Jaringan keras gigi yang termineralisasi akibat adanya asam hasil fermentasi karbohidrat oleh mikroorganisme, akan menjadi larut dan rusak. Hal ini kemudian diikuti dengan kerusakan bahan organik gigi akibat enzimenzim yang bersifat proteolitik yang dihasilkan oleh berbagai jenis mikroorganisme. Akibat lebih lanjut adalah terjadi invasi mikroorganisme, yang kemudian dapat diikuti dengan kematian gigi dan penyebaran infeksi ke dalam jaringan periapikal. $^{4,5}$

Karies gigi dapat timbul pada satu permukaan gigi atau lebih dan dapat meluas ke bagian yang lebih dalam. Karies gigi dapat disebabkan: karbohidrat, mikroorganisme dan air ludah, permukaan dan bentuk gigi. Gigi dengan fisur yang dalam mengakibatkan sisa-sisa makanan mudah melekat dan bertahan, sehingga produksi asam oleh bakteri akan berlangsung lebih cepat dan menimbulkan karies gigi. ${ }^{2}$

Keasaman mulut merupakan hasil metabolisme mikroorganisme pada sukrosa dapat mengakibatkan proses demineralisasi permukaan gigi. Asam biasanya terletak di bagian bawah dari plak yang melindungi gigi dari suasana basa. Dengan alasan inilah maka berkumur dengan air setelah makan tidak dapat menghilangkan asam, meskipun dapat sedikit melarutkan asam beserta sukrosa yang terdapat pada permukaan luar plak. Bakteri tertentu pada plak berubah menjadi amonia yang dapat menetralisir asam. Apabila asam terus-menerus dihasilkan maka pH menjadi lebih rendah dan mencapai derajat keasaman 5,5 dimana proses demineralisasi kalsium dan phosphor dari email dimulai. ${ }^{6}$

Agrerat kuman asidogenik di dalam plak gigi, akan memfermentasi sakar diet menjadi berbagai asam. Sumber utamanya adalah sukrosa yang masuk ke dalam plak gigi, sedangkan secara kuantitatif, sumber utama 
adalah sukrosa. Penyebab utama terbentuknya asam tadi adalah Streptococcus mutans yang terdapat di dalam plak karena bakteri ini memetabolisme sukrosa menjadi asam lebih cepat dibandingkan bakteri lain dalam agrerat. ${ }^{7}$

\section{METODE PENELITIAN}

Penelitian dilakukan secara survei analitik dengan rancangan penelitian cross sectional pada pasien yang memiliki kareis gigi di RSGM Baiturrahmah. Populasi penelitian adalah pasien yang memiliki karies gigi pada usia 16-25 tahun di RSGM Baiturrahmah. Sampel sebanyak 35 pasien yang berusia 1625 tahun, laki-laki dan perempuan di RSGM Baiturrahmah.

Pengumpulan data dilakukan dengan cara observasi, yaitu pengambilan data dilakukan dengan cara pengukuran karies gigi dengan indeks DMF-T dan melakukan penelitian keasaman mulut dengan $\mathrm{pH}$ meter universal indikator. Data yang diperoleh kemudian dengan uji statistik oneway anlyst of variant (ANOVA)

\section{HASIL PENELITIAN}

Penelitian ini telah dilakukan pemeriksaan pada pasien di RSGM Universitas Baiturrahmah Padang, sampel diambil sebanyak 35 orang yang diambil secara simple random sampling. (Tabel 1.)
Tabel 1. Distribusi Rata-Rata Keasaman Mulut Responden Terhadap Karies Gigi

\begin{tabular}{ccc}
\hline Karies & pH rata-rata & $\rho$ \\
\hline Ringan & $7,13 \pm 0,97$ & \\
Sedang & $5,75 \pm 0,46$ & $0,000^{*}$ \\
Berat & $4,25 \pm 0,50$ & \\
\hline rangan : *Signifikansi $\rho<0,05$ &
\end{tabular}

Berdasarkan tabel di atas dapat dilihat $\mathrm{pH}$ rata-rata kelompok karies gigi yaitu $\mathrm{pH}$ ratarata kelompok karies gigi ringan 7,13 $\pm 0,97$, $\mathrm{pH}$ rata-rata kelompok karies gigi sedang $5,75 \pm 0,46$ dan $\mathrm{pH}$ rata-rata kelompok karies gigi berat 4,25 $\pm 0,50$. Setelah diuji statistik dengan ANOVA, terdapat perbedaan yang cukup signifikan ketiga kelompok diatas $(\rho=$ $0,000)$.

Tabel 4.2 Perbandingan $\mathrm{pH}$ saliva pada kelompok

\begin{tabular}{cccc}
\multicolumn{4}{c}{ karies gigi ringan, sedang dan berat } \\
\hline Kelompok & $\begin{array}{c}\text { Karies } \\
\text { Ringan }\end{array}$ & $\begin{array}{c}\text { Karies } \\
\text { Sedang }\end{array}$ & $\begin{array}{c}\text { Karies } \\
\text { Berat }\end{array}$ \\
\hline Karies & - & $0,001^{*}$ & $0,000^{*}$ \\
Ringan & & & $0,020^{*}$ \\
Karies & - & - & - \\
Sedang & & - & - \\
Karies Berat & - & - &
\end{tabular}

Berdasarkan tabel di atas terlihat perbandingan $\mathrm{pH}$ saliva pada kelompok karies gigi ringan, sedang dan berat. Terdapat perbedaan $\mathrm{pH}$ saliva yang cukup signifikan antara kelompok karies gigi ringan dengan sedang $(\rho=0,001)$, demikian juga pada kelompok karies gigi ringan dengan berat cukup signifikan $(\rho=0,000)$ dan pada kelompok karies gigi sedang dengan berat terlihat perbedaan yang cukup signifikan juga $(\rho=0,020)$. Setelah diuji statistik, terlihat perbedaan yang cukup signifikan ketiga kelompok di atas $(\rho<0,05)$. 


\section{PEMBAHASAN}

Distribusi rata-rata keasaman mulut responden terhadap karies gigi dapat dilihat berdasarkan tabel $4.1 \mathrm{di}$ atas. Dari tabel tersebut dapat dilihat tingkat keasaman mulut $(\mathrm{pH})$ terhadap karies gigi yaitu $\mathrm{pH}$ rata-rata kelompok karies gigi ringan 7,13 $\pm 0,97, \mathrm{pH}$ rata-rata kelompok karies gigi sedang 5,75 \pm 0,46 dan $\mathrm{pH}$ rata-rata kelompok karies gigi berat $4,25 \pm 0,50$. Setelah diuji dengan ANOVA terdapat perbedaan yang signifikan diantara ketiga kelompok $(\rho=0,000)$. Perbandingan ketiga kelompok menunjukkan adanya hubungan yang bermakna yaitu makin banyak gigi yang terkena karies maka derajat keasaman $(\mathrm{pH})$ makin asam.

Berdasarkan hasil yang diperoleh dalam penelitian tentang keasaman mulut terhadap karies gigi pada usia 16 - 25 tahun di RSGM Baiturrahmah Padang tahun 2011 disimpulkan sebagai berikut : 1). Karies gigi ringan $\mathrm{pH}$ rata-rata $7,13 \pm 0,97$, karies gigi sedang $\mathrm{pH}$ rata-rata $5,75 \pm 0,46$ dan karies gigi berat $\mathrm{pH}$ rata-rata $4,25 \pm 0,50 ; 2$ ) perbedaan ketiga kelompok menunjukkan hubungan yang bermakna yaitu makin banyak gigi yang terkena karies maka derajat keasaman $(\mathrm{pH})$ makin asam.

\section{KESIMPULAN}

Ada beberapa hal yang harus dilakukan dan diperhatikan pasien untuk kebersihan mulutnya yaitu : 1) Membersihkan mulut secara menyeluruh dengan sikat dan benang gigi (floss), menggunakan tongue scraper untuk menyingkirkan lapisan putih pada lidah. 2) Menghindari makanan seperti: kuekue, permen, dan coklat yang dapat menempel pada permukaan gigi yang dapat menyebabkan karies gigi. 3) Menyikat gigi setiap hari minimal 2 x sehari; pada waktu pagi hari dan malam sebelum tidur, lamanya menyikat gigi dianjurkan minimal selama 2-3 menit. 4) Menghindari melakukan terapi sinar dan mengkonsumsi obat-obatan yang dapat menghambat produksi saliva. 5) Memeriksakan gigi secara rutin 1 x 6 bulan untuk menghindari penumpukan plak sehingga menimbulkan keasaman mulut yang dapat menyebabkan karies gigi. 6) Memeriksakan gigi secara rutin 1 × 6 bulan untuk menghindari penumpukan plak sehingga menimbulkan keasaman mulut yang dapat menyebabkan karies gigi.

\section{DAFTAR PUSTAKA}

1. Hausen, Tenuvou dan Mazengo. 1996. Commuty Dentistry And Oral Epidemiology. Munksgaard.Hal 1,7.

2. Tarigan, R. 1995. Karies Gigi. Editor. Drg. Lilian Yuwono. Hipokrates. Hal 1,17-25 34, 40 - 47, 53.

3. Panjaitan, M. 1993. Buku Kumpulan Makalah Ilmiah. Medan. Hal: 21-23.

4. Lawler, W. 2002. Buku Pintar Patologi Untuk Kedokteran Gigi. Alih Bahasa: Agus Djaya. Editor. Wiliam Yuwono. Jakarta : EGC. Hal: 80.

5. Koerniati, I. 2006, Perkembangan Perawatan Gigi Masa Depan. Lustrum Unand ke X. Padang. Hal: 120-122.

6. Sundoro, E.H. 2005. Serba-Serbi Ilmu Konservasi Gigi. Jakarta. UI-Press. Hal 59, 63-64.

7. Roeslan, B.O. 2002. Imunologi Oral: Kelainan di Dalam Rongga Mulut. Balai Penerbit Fakultas Kedokteran Universitas Indonesia. Jakarta. Hal: 139-140.

8. Kidd, E.A.M. 2000. Manual Konservasi 
Restorative Menurut Pickard. Ed.6. Alih Bahasa: Narlan Sumawinta. Widya Medika, Jakarta. Hal: 4,5, 29, 45, 52.

9. Langlais, R.P. 2000. Atlas Berwarna Kelainan Rongga Mulut Yang Lazim. Alih Bahasa: Budi Sosetyo. Editor Lilian Yuwono. Jakarta: Hipokrates. Hal: 18.

10. Suwelo, I. S. 1992. Karies Gigi Pada Anak Dengan Berbagai Faktor Etiologi. Ed. Ke-1. Jakarta. Hal8, 23 - 28.

11. Fort, P. 1992. Restorasi Gigi. Ed. Ke-2. Alih Bahasa : Sumawinata, N. EGC. Jakarta. Hal $1-6$.

12. Kidd, E.A.M, Bechal, S.J. 1992. Dasar Dasar Karies: Penyakit dan Penanggulangannya. Penerjemah Narlan Sumawita dan Safrida Haruk. EGC. Jakarta. Hal $1-4$.

13. Pinkham, J.R. 2005. Pediatric Dentistry: Infancy Through Adolescence. Fourth Edition. Elsevier Saunders. St. Louis, Missouri. Hal 202 - 203.

14. Mount, G.J. Hume, W.R. 2005. Preservation and Restoration of Tooth Structure. Knowledge Books and Software. Australia. Hal $113-116$.

15. Summitt, Jamws, dkk. 2006. Fundamentals of Operative Dentistry A Contemporary
Approach. Editor Lindsay Harmon. China. Hal: 89.

16. Sage Publication. Calsium Sodium Phosphosilicate (NovaMin): Remineralization Potential. htpp://adr.sagepub.com/content/21/1/35. 9 Januari 2011.

17. Sage Publication. Remineralization, the Natural Caries Repair Process-The Need for New Approaches. http://adr.sagepub.com/content/21/1/4. 9 Januari 2011.

18. Godoy, F. G, Hicks, M.J. Mainting the integrity of the enamel surface: The role of dental biofilm, saliva and remineralization preventive agents in enamel demineralization.

Htpp://jada.ada.org/cgi/content/full/139/sup pl_2/25s.9 Januari 2011.

19. Supartinah, AI. 2001. Pencegahan Terbentuknya Karies Baru Berdasarkan Ekspresi Faktor Resiko Dari Cariogram Pada Anak. Yogyakarta. Hal 393 - 397.

20. Prasetyanti, R.E. 2008. Efek Topical Fluoride Terhadap Resiko Karies Ditinjau dari $\mathrm{pH}$ Plak dan pH Saliva Pada Pasien Yang Menggunakan Alat Orthodonti Cekat. Jakarta. Hal: 4, 7,12-14. 